\title{
INVESTIGATION ON TRADE OF ÇORUM WITH SURROUNDING PROVINCES BY GRAVITY MODEL
}

\author{
Muhammed Hasan YÜCEL ${ }^{1}$
}

Citation/( : Yücel, M., H. (2021). Investigation on trade of Çorum with surrounding provinces by gravity model. Hitit Journal of Social Sciences, 14(1), 287-301. doi: 10.17218/hititsbd.884454

Abstract: In this study, the trade relationship of Çorum province with the surrounding provinces was examined by using Newton's Gravity Model. Newton's Gravity Model is used to model the gravitational forces of planets and their physical states in space. It is possible to adapt this model to inter-provincial or inter-country trade relations. The analysis results show that the Gravity Model has a strong representation property in explaining inter-provincial trade of Çorum where has a great potential to further develop the commercial relations it has with its neighbours. In addition, it was found that Nevşehir and Karabük are, two neighbours but close cities to Çorum, remained below the potential and the sales volume of Çorum to these provinces was low.

Keywords: Gravity Model, Çorum, Inter-Provincial Trade, Newton, OLS.

\section{Çorum'un Çevre IIller ile Olan Ticaretinin Çekim Modeli ile İncelenmesi}

Atıf/(): Yücel, M., H. (2021). Çorum'un çevre iller ile olan ticaretinin çekim modeli ile incelenmesi. Hitit Sosyal Bilimler Dergisi, 14(1), 287-301. doi: 10.17218/hititsbd.884454

Özet: Bu çalışmada Çorum ilinin çevre iller ile olan ticaret ilişsisi Newton'un Çekim Modeli ile incelenmiştir. Newton'un Çekim Modeli gezegenlerin çekim kuvvetlerini ve uzaydaki fiziki durumlarını modellemek için kullanılmaktadır. Bu modeli iller arası ya da ülkeler arası ticari ilişkilere uyarlamak mümkündür. $\mathrm{Bu}$ çalışmada ise 2017 yılına ait Çorum ve diğer iller arası ticaret verileri kullanılmıştır. Analiz sonucunda iller arası ticareti açıklamada Çekim Modeli’nin güçlü bir temsiliyet özelliğine sahip olduğu görülmüştür. $\mathrm{Bu}$ analize göre Çorum’un komşuları ile sahip olduğu ticari ilişkileri daha da geliştirebileceği yönünde büyük bir potansiyele sahip olduğu ortaya konmuştur. Ek olarak Çorum’a komşu olmayıp görece yakın olan Nevşehir ve Karabük'ün Çorum ile ticaretlerinin potansiyelin altında kaldığı, Çorum'un bu illere satış miktarının düşük olduğu tespit edilmiştir.

Anahtar Kelimeler: Çekim Modeli, Çorum, İller Arası Ticaret, Newton, OLS.

\section{INTRODUCTION}

The factors hindering international relations reduces the commercial potential of countries. By the international trade agreements made and, especially after the 1980s, with the acceleration of globalization, international commercial, social, cultural and political interactions have increased. The distance of the trade centers to each other, their production capacities, income levels and their location on trade routes determine the trade volume. In this article, the commercial relationship of a trade center with its surrounding trade centers is examined by the Gravity Model.

The Gravity Model was first used in economics by Jan Tinbergen in 1962. Using this model, Jan Tinbergen stated that countries can be perceived as objects with physical weight, upon considering the GDP data, and commercial relations with each other can be physically realized by considering the distance between them (Golovko, 2009, p.3). As the distance between countries 
increases due to transport costs, the trade volume decreases. As countries' national incomes increase, their purchasing power will increase, so will trade volume. In other words, there is a negative relationship between the trade volume among countries and the distance, whereas there is a positive relationship between national income and the distance (Tatlic1 and K1z1ltan, 2011, p.288).

This model is named after Newton's famous Law of Gravity. According to this law, there is a gravitational force between two bodies with mass, and this gravitational force is directly proportional to the masses of the bodies, inversely proportional to the distance between the bodies. Upon adapting it to the science of economics, there is a gravitational force between two economic units that is directly proportional to the trading capacities of the units, while there is a gravitational force inversely proportional to the distance between them.

$F=G \frac{m_{1} m_{2}}{r^{2}}$

Newton's Law of Gravity formula is shown in Equation (1). The mathematical meaning of this equation is that the gravitational force between two bodies with a mass of $m_{1}$ and $m_{2}$ is inversely proportional to the square of the distance between them $\left(\mathrm{r}^{2}\right)$. In this study, it is tried to explain the trade relations between Çorum province and the surrounding provinces using the Gravity Model.

Çorum province is bordered by the Central Black Sea region and the Central Anatolia region by Amasya, Çankırı, Yozgat, Sinop, Samsun, Kastamonu and Kırıkkale provinces. Çorum is a gateway connecting Central Anatolia to the Black Sea (Çorum Provincial Food and Livestock Report, 2017, p.1).

According to the Entrepreneur Information System 2017 data of the Ministry of Science of TR, Industry and Technology, ten provinces have sales surpluses while Kocaeli, İstanbul and İzmir are the first three provinces with sales surplus. 71 provinces have deficits in total while Antalya, Konya and Trabzon are among the top three provinces with the highest deficit. The total domestic trade volume is 4 trillion 323 billion TL which İstanbul provides approximately $49 \%$ of this trade volume alone. İstanbul, Ankara and İzmir, three metropolitan cities, provide $66 \%$ of the total trade volume.

Table 1. Top 10 Provinces with Trade Surplus and Deficit in Inter-Provincial Trade Relations (2017) (Million TL)

\begin{tabular}{lrlr}
\hline \hline \multicolumn{2}{c}{ Trade Surplus Provinces (Sale-Purchase) } & \multicolumn{2}{c}{ Trade Deficit Provinces (Sale-Purchase) } \\
\hline \hline Kocaeli & 91.712 & Antalya & -17.790 \\
İstanbul & 81.364 & Konya & -10.119 \\
İzmir & 27.370 & Trabzon & -9.534 \\
Hatay & 7.471 & Bursa & -9.069 \\
Zonguldak & 3.451 & Sakarya & -8.598 \\
Karabük & 1.705 & Gaziantep & -7.916 \\
Osmaniye & 588 & Denizli & -6.873 \\
Bolu & 226 & Adana & -6.106 \\
Yalova & 202 & Ankara & -5.997 \\
Kilis & 25 & Samsun & -5.897 \\
\hline \hline
\end{tabular}

Source: T.C. Ministry of Science, Industry and Technology, Entrepreneur Information System 2017 (https://gbs.sanayi.gov.tr). 
Commercial sales volumes of Çorum throughout Turkey rank second after Samsun, which has metropolitan status compared to its neighbors. In Table 2, it is seen that Sinop performs the least "sales and purchase volume" in inter-provincial trade while the largest trade deficit occurs in Samsun, whereas the least occurs in Sinop.

Table 2. Inter-Provincial Trade of Çorum and Its Neighbors (2017) (Million TL)

\begin{tabular}{lrrr}
\hline \hline Provinces & Total Sales & Total Purchase & Sales-Purchase \\
\hline \hline Samsun & 27.011 & 32.908 & -5.896 \\
Çorum & 9.984 & 12.768 & -2.783 \\
Yozgat & 5.839 & 7.468 & -1.629 \\
Kastamonu & 4.562 & 6.026 & -1.464 \\
Kirıkkale & 4.190 & 5.148 & -957 \\
Amasya & 3.689 & 4.937 & -1.248 \\
Çankırı & 2.633 & 3.372 & -739 \\
Sinop & 951 & 1.676 & -725 \\
\hline \hline
\end{tabular}

Source: T.C. Ministry of Science, Industry and Technology, Entrepreneur Information System 2017 (https://gbs.sanayi.gov.tr).

When it is looked at the Entrepreneurial Information System (2017) data, the total volume of trade between Çorum and other neighboring provinces was 23.306 million TL. There are only two provinces between Çorum and neighboring provinces that do trade deficits Çorum (336 million TL) and Samsun (192 million TL). Table 3 shows the trade volumes between Çorum and other provinces.

Table 3. Trade of Çorum and its Neighbors with Each Other (2017) (Million TL)

\begin{tabular}{|c|c|c|c|c|c|c|c|c|}
\hline \multirow[b]{2}{*}{$\begin{array}{l}\text { Selling } \\
\text { Provinces }\end{array}$} & \multicolumn{8}{|c|}{ Purchasing Provinces } \\
\hline & Amasya & Çankırı & Çorum & Kastamonu & Kirıkkale & Samsun & Sinop & Yozgat \\
\hline Amasya & 1.038 & 3 & 131 & 11 & 69 & 375 & 9 & 15 \\
\hline Çankır1 & 10 & 466 & 28 & 82 & 11 & 60 & 2 & 3 \\
\hline Çorum & 169 & 109 & 3.845 & 71 & 98 & 493 & 20 & 133 \\
\hline Kastamonu & 3 & 29 & 25 & 1.028 & 2 & 204 & 50 & 6 \\
\hline Kırıkkale & 27 & 29 & 49 & 3 & 906 & 109 & 2 & 23 \\
\hline Samsun & 483 & 55 & 472 & 201 & 81 & 9.299 & 229 & 52 \\
\hline Sinop & 6 & 0,8 & 8 & 25 & 1 & 78 & 263 & 1,7 \\
\hline Yozgat & 5 & 14 & 43 & 7 & 26 & 60 & 2 & 2.145 \\
\hline
\end{tabular}

Source: T.C. Ministry of Science, Industry and Technology, Entrepreneur Information System 2017 (https://gbs.sanayi.gov.tr).

Compared to its neighbors, Çorum has the highest ratio of commercial sales to commercial purchases. As can be calculated from Table 4, the share of Çorum in the total trade volume in its region is approximately $21 \%$. Considering the commercial relations among themselves, Çorum ranks first in terms of income per capita with 9.346 TL 2017, Samsun ranked second with 8.280 TL and Yozgat ranked third with 5.500 TL. Sinop is in the last place with 1.850 TL. 
Table 4. Trade Volumes Between Çorum and its Neighbors (2017) (TL)

\begin{tabular}{lrrrrr}
\hline \hline Provinces & Total Sales & Total Purchase & Surplus & Population & $\begin{array}{r}\text { Per Capita } \\
\text { Income }\end{array}$ \\
\hline \hline Çorum & 4.938 .538 .699 & 4.601 .791 .911 & 336.746 .788 & 528422 & 9.346 \\
Samsun & 10.871 .722 .434 & 10.679 .048 .310 & 192.674 .124 & 1312990 & 8.280 \\
Çankır1 & 662.771 .043 & 705.621 .204 & -42.850 .161 & 186074 & 3.562 \\
Kirıkkale & 1.148 .429 .662 & 1.194 .008 .779 & -45.579 .117 & 278749 & 4.120 \\
Yozgat & 2.302 .759 .631 & 2.380 .185 .134 & -77.425 .503 & 418650 & 5.500 \\
Kastamonu & 1.347 .488 .058 & 1.427 .450 .786 & -79.962 .728 & 372373 & 3.619 \\
Amasya & 1.650 .477 .014 & 1.740 .804 .780 & -90.327 .766 & 329888 & 5.003 \\
Sinop & 383.819 .025 & 577.094 .662 & -193.275 .637 & 207427 & 1.850 \\
\hline \hline
\end{tabular}

Source: T.C. Ministry of Science, Industry and Technology, Entrepreneur Information System 2017 (https://gbs.sanayi.gov.tr).

Table 5 shows that the contribution of the income obtained from the sales made with Amasya, which is the closest province to Çorum, to the per capita income of Çorum is 320 TL per year. The highest contribution to annual per capita income for Çorum is obtained from the trade made with Samsun, among the first five provinces closest to Çorum. The income from this trade is $933 \mathrm{TL}$ per person per year. Çorum's income from trade throughout Turkey is 18.895 TL per person. 5.547 TL of which is coming from trade with İstanbul and Ankara. Among the top five provinces closest to Çorum, Samsun is the province with the most annual per capita income derived from trade volume throughout Turkey with 20.572 TL followed by Kirlkkale with 15.035 TL. The contribution of the top five provinces farthest to Çorum to the annual per capita income of Çorum is about $52 \mathrm{TL}$ in total.

Table 5. Commercial Sales Volume of Çorum with the Top 5 Provinces Closest and Furthest to Çorum (2017) (TL)

\begin{tabular}{lrrr}
\hline \hline & Sales Volume & Distance (km) & Per Capita Sales Volume \\
\hline \hline Amasya & 169.147 .928 & 92 & 320 \\
Yozgat & 133.110 .103 & 108 & 252 \\
Çankırı & 109.289 .670 & 156 & 207 \\
Kırıkkale & 97.795 .177 & 166 & 185 \\
Samsun & 492.887 .111 & 172 & 933 \\
Iğdır & 11.657 .576 & 939 & 22 \\
Siirt & 1.713 .664 & 949 & 3 \\
Şırnak & 3.278 .421 & 1045 & 6 \\
Van & 11.199 .189 & 1058 & 21 \\
Hakkâri & 203.582 & 1230 & 0,4 \\
\hline \hline
\end{tabular}

Source: T.C. Ministry of Science, Industry and Technology, Entrepreneur Information System 2017 (https://gbs.sanayi.gov.tr), General Directorate of Highways, TurkStat (Address Based Population Registration System, 2017).

Note: The population of Çorum in 2017 is 528.422 people.

\section{LITERATURE REVIEW}

The Gravity Model has been used often in international trade, tourism and migration studies in the literature. However, this model was used only in one study to examine the structure of trade relations between provinces in Turkey as far as it is found. In this respect, it can be said that this study will be the second study (The First Study; Yaşar ve Korkmaz, 2018) and will contribute to the literature in terms of being a more up-to-date are using 2017 data. In addition, this study is the first study on this subject for Çorum. When it is looked at the literature, there are many studies in which the scope is different but the model is the same. 
Ratnayake and Townsend (1999) analyzed the geographical pattern of New Zealand's foreign trade using the Gravity Model. In their study, to explain New Zealand's exports and imports, basic explanatory variables such as income and population, as well as some dummy variables were used to capture the special relationship between New Zealand trading partners. The Model was estimated for each year from 1987 to 1992, using pooled cross-sectional and time-series data, and the stability of the coefficients of the independent variables was tested. While most of the previous studies were done for a single year, ignoring fluctuations over time, this study focused on a six-year period. In the study, it has been determined that the transition of socialist market economies to a market-oriented economic structure will increase the trade volume between New Zealand and the west to a higher level. Besides, it was emphasized that trade liberalization initiatives proposed within the scope of Asia Pacific Economic Cooperation (APEC) will directly affect the countries with which New Zealand does trade above average will positively change New Zealand trade.

Abraham and Hove (2005), in their study, used a 9-year (1992-2000) panel dataset of 23 countries. It was determined that China benefited from the trade agreement with the Association of Southeast Asian Nations (ASEAN) in terms of export potential and at the same time, an agreement to be made with South and East Asian countries could have great export potential.

Kucharčuková et al. (2010) performed a panel data analysis using the Poisson and Tobit estimation techniques with an 8-year (1997-2004) data set of 82 countries. In the study using the Gravity Model, the reason why Southeast Europe (SEE) and Commonwealth of Independent States (CIS) countries trade significantly less with the world economy than the later participating Central and Eastern European (CEE) Countries was investigated. The main reason for this was seen as the presence of low-quality economic institutions in SEE and CIS countries. Also, the study found that for some CIS countries, the distance to markets and the case being surrounded by land are quantitatively less important than the weaknesses in the quality of institutions or infrastructure quality.

Tatlic1 and Kiziltan (2012), in their study, used 14 years of panel data covering 46 countries and 1994-2007. Turkey's export-dependent variable of the model is that the population of the country, from the capital Ankara and GDP were used as independent variables. In addition, in the model where customs union and common border dummy variables are used, the coefficients of the population variables of the countries are found to be meaningless, while the coefficients of the other variables are found to be significant and appropriate to the theory. Meaningless out of the common border dummy variable is linked to the problems experienced by Turkey's neighboring countries. Finally, there is no significant impact on the customs union and the common border of Turkey's exports.

Gencer and Öngel (2011) investigated the potential trade volume between Syria, Lebanon and Jordan within the framework of the free trade zone. The model used in the study of the Gravity Model of the foreign trade volume between Turkey and these countries was found to be lower than expected. Thus, a free trade zone agreement between these countries and Turkey is expected to be beneficial for Turkey.

Ata (2013) analyzed the potential trade volume between Turkey's neighboring countries between 1980-2009 with using the Gravity Model. Ten countries with potential trade volume among 68 countries were analyzed. Turkey's neighboring countries with important findings of this study in terms of carry trade below its potential revealed. This shows that Turkey is not able to use the 
trade advantage brought by its neighbourly situation. This has been linked to social and political instability in surrounding countries.

Bindak (2015) established a model using inter-provincial migration and happiness level, number of divorces, attraction coefficient of provinces, and other data from 2011-2012. An estimate of migration from any $\mathrm{i}$ province to $\mathrm{j}$ province can be made by means of the established model. In addition, Bindak calculated the attraction coefficient for each provinces. The attractiveness coefficient of a province is positively related to the rough divorce rate of that province and the unemployment rate in the province, and negatively related to the provincial ranking of the transition to higher education exam.

Yaşar and Korkmaz (2018) researched the trade with other provinces of Kütahya by the Gravity Model. In their study, which used inter-provincial trade data for 2013, GDP data was used to represent the economic size of the provinces, while the distance of the provinces in $\mathrm{km}$ terms was used for distance. The commercial relations of Kütahya province and other provinces yielded results consistent with the Gravity Model by them. According to this result, the GDP of the provinces positively affects the commercial sales between the province of Kütahya and the other provinces, while the distance between the provinces negatively affects the commercial sales among the other provinces. In the light of this information, it is concluded that Kütahya is prone to trade with developed provinces.

\section{DATA, METHOD AND FINDINGS}

The data of this study was taken from the Ministry of Science, Industry and Technology, Entrepreneur Information System. Since only data for 2017 are available, the study is limited to 2017 data. The distance between provinces is based on the data of the General Directorate of Highways. In this investigation, where the inter-provincial trade analysis of Çorum and 80 other provinces were conducted, the model based on the Gravity Model was estimated via the E-views software with Ordinary Least Squares Model.

Here is how Equation (1) in the introduction section of Newton's Law of Gravity is applied to interprovincial trade;

- $\mathrm{T}_{\mathrm{ij}}$ : Trade between provinces $\mathrm{i}$ (Çorum) and $\mathrm{j}$ (other provinces)

- $Y_{i}$ ve $Y_{j}$ : Per capita income of provinces $i$ and $j$

- $\mathrm{D}_{\mathrm{ij}}$ : Geographical distance between provinces $\mathrm{i}$ and $\mathrm{j}$

$T_{i j}=G \frac{Y_{i}^{\alpha} Y_{j}^{\beta}}{D_{i j}^{\theta}} \varepsilon_{i j}$

The natural logarithm of Equation (2) was taken and converted to a linear equation. This equation shows how Çorum has a relationship with the sales amounts $\left(T_{i j}\right)$ to other provinces and the per capita income $\left(Y_{j}\right)$ of that province and the distance between them. In Equation (3) predicted with OLS, in line with the Gravity Model, the expected value of the coefficient $\beta$ is positive while the expected value of the coefficient $\theta$ is negative. The $\beta$ coefficient is the parameter that indicates income elasticity and the $\theta$ coefficient is the distance elasticity. The term $G$ in Equation (2) is the constant term of the model. Since the per capita income of the province of Çorum is taken for 2017 , it will take the value of $Y_{i}$ each time for all equations. In other words, the value of $Y_{i}$ is in the constant $a$ along with the constant $G$ (Yassar and Korkmaz, 2018, p. 101).

$\log T_{i j}=\alpha+\beta \log Y_{j}+\theta \log D_{i j}+\varepsilon_{i j}$ 
Table 6 with summary statistics of variables is given below. In the study involving 80 provinces, the average value of the logarithm of the distance of the province of Corum to other provinces is 6,25 and the minimum and maximum values are 4,52 and 7,11 respectively. Data for other values can be seen in Table 6.

Table 6. Descriptive Statistics

\begin{tabular}{crrrrrr}
\hline \hline & Obs. & Mean & Median & Max & Min & Std. Dev. \\
\hline \hline $\mathrm{T}_{\mathrm{ij}}$ & 80 & 16,538 & 16,395 & 21,305 & 11,050 & 1,802 \\
$\mathrm{Y}_{\mathrm{j}}$ & 80 & 9,659 & 9,654 & 11,864 & 7,640 & 0,818 \\
$\mathrm{D}_{\mathrm{ij}}$ & 80 & 6,251 & 6,371 & 7,114 & 4,521 & 0,543 \\
\hline \hline
\end{tabular}

Note: All variables are expressed in natural logarithm.

As can be seen from Table 7 , the amount of sales made by Çorum is positively correlated with per capita income in the province where it sells, and is negatively correlated with the distance between the province it sells. According to OLS results, a $1 \%$ increase in per capita income in the province where Çorum is selling, increases the sales volume of Çorum by $1,22 \%$. On the other hand, the increase in the distance between Çorum and the province it sells by $1 \%$, reduces the sales volume of Çorum by $1,56 \%$. Other OLS estimates also gave roughly the same results.

Table 7. Results of the OLS

\begin{tabular}{lrrrr}
\hline \hline & OLS & Robust OLS (M) & Robust OLS (S) & Robust OLS (MM) \\
\hline \hline Constant & $14,518^{* * *}$ & $15,549^{* * *}$ & $14,348^{* * *}$ & $15,537^{* * * *}$ \\
& $(0,000)$ & $(0,000)$ & $(0,000)$ & $(0,000)$ \\
$Y_{j}$ & $1,223^{* * *}$ & $1,130^{* * *}$ & $1,286^{* * *}$ & $1,131^{* * *}$ \\
$D_{i j}$ & $(0,000)$ & $(0,000)$ & $(0,000)$ & $(0,000)$ \\
$R^{2}$ & $-1,567^{* * *}$ & $-1,581^{* * *}$ & $-1,596^{* * *}$ & $-1,581^{* * *}$ \\
Adj-R & $(0,000)$ & $(0,000)$ & $(0,000)$ & $(0,000)$ \\
Prob(F-statistic) & 0,583 & 0,472 & 0,385 & 0,473 \\
Number Of Observations & 0,572 & 0,458 & 0,369 & 0,460 \\
Pumber & 0,000 & 0,000 & 0,000 & 0,000 \\
\hline
\end{tabular}

Notes: All variables are in logs in the series. The values in parentheses give p-values. ${ }^{*},{ }^{* *},{ }^{* * *}$ indicate $10 \%, 5 \%$ and $1 \%$ significance levels, respectively.

The $0,58 \mathrm{R}^{2}$ value of the OLS model shows $58 \%$ of the changes in the dependent variable in the model are explained by the independent variables. The estimation of this model by other econometric methods yielded similar results. $\mathrm{R}^{2}$ values of Robust OLS results are also very close compared to normal OLS results.

The F statistic showing the significance of the OLS model was 53,88 . Since the probability value of the $\mathrm{F}$ statistic is $[\mathrm{P}=0,000]<0,01$, the model is completely meaningful. Other significance test results of the model are seen in the Table 8.

Table 8. Diagnostic Tests for OLS Regression

\begin{tabular}{llrr}
\hline \hline Test Statistics & Test Applied & Test-statistics & Prob. \\
\hline \hline VIF & Variance Inflation Factors & 1,009 & - \\
Normality & Test of Jarque-Bera & 2,082 & 0,352 \\
Heteroscedasticity & Glijser Test & 1,995 & 0,142 \\
Serial Correlation LM & Breusch-Godfrey & 0,087 & 0,916 \\
\hline \hline
\end{tabular}

It is possible to determine whether the provinces are above or below their trade potential based on the studies of Batra (2004), Ram and Prasad (2007). The difference between the estimated 
values (E) and the actual trade values (A) are looked according to the approach of the two authors. If $\mathrm{E}>\mathrm{A}$, the trade current remains below the potential. If $\mathrm{E}<\mathrm{A}$, the trade current is above the potential. In Graph 1 (in ANNEX-3), while Çorum conducts trade above its potential with provinces with a value above zero, it conducts trade below its potential with provinces below zero. It can be said that there are great trade potentials between Çorum and Karaman, Kilis, Tunceli. On the other hand, Çorum has a trading volume above its potential with Mardin, Istanbul and Kars.

When it is looked at the neighbors of Çorum, only Yozgat has a trade below its potential. In Table 9, the OLS results of Çorum's neighbors are shown numerically. Samsun became the province that carried out trade with Çorum far above its potential. Other neighboring provinces are slightly above the potential. Trade of Çorum with these provinces has the opportunity to increase much more with the commercial opportunities developed. As can be seen from the Annex-2 table, there are also non-neighboring provinces that are relatively close to Çorum and remain below the trade potential. The two most notable provinces are Nevşehir and Karabük. Although these two provinces are approximately $300 \mathrm{~km}$ away from Çorum, trade is far below the relative potential.

Table 9. Potential Trade with Neighbors of Çorum as a Result of OLS

\begin{tabular}{lrrr}
\hline \hline Provinces & Actual Values & Estimated Values & Residuals \\
\hline \hline Samsun & 20,02 & 18,60 & 1,41 \\
Çankirı & 18,51 & 18,30 & 0,21 \\
Kırikkale & 18,40 & 18,28 & 0,12 \\
Yozgat & 18,71 & 18,86 & $-0,15$ \\
Kastamonu & 18,08 & 17,76 & 0,33 \\
Amasya & 18,95 & 18,84 & 0,11 \\
Sinop & 16,79 & 16,08 & 0,70 \\
\hline \hline
\end{tabular}

Although the distance is not the only factor leading below potential trade, it cannot be denied that this factor is an important parameter affecting the trade volume. When evaluated from this point of view, there are many factors affecting the structure of commercial potential between provinces, but these are taken as ceteris-paribus in this study. The potential commercial status of Çorum with all other provinces is demonstrated in ANNEX-1 and ANNEX-2 tables.

\section{CONCLUSION}

The investigation, where the potential trade volume of Çorum was analyzed, concluded that results are coherent with the Gravity Model. In this study, similar results were obtained with other studies in the same field. For example; in a study conducted specifically for Kütahya province for Turkey (Yaşar and Korkmaz, 2018), a positive relationship between the GDP of the provinces and the commercial sales made between Kütahya was found. In addition, a negative relationship has been revealed with the commercial sales of Kütahya between provinces and the provinces distances. In another similar study (Kucharčuková et al., 2010), it was found that the distance to the markets is less important than the quality of the institutions on the trade volume. Again, in another study (Ata, 2013), the trade volume of Turkey with its neighbors was investigated with the Gravity Model and it was determined that Turkey could not fully use its neighborly advantage and conducts trade with its neighbors below its potential trade volume. In this study, the Gravity Model was applied in a similar way by adapting it to inter-provincial trade instead of international trade. The determinations made as a result of the application are in parallel with other studies in the literature.

The contribution of this study to the literature is being the first study conducted specifically for Çorum with 2017 data and being the second study (the first study is Yaşar and Korkmaz, 2018) 
applied to trade between provinces in Turkey. According to OLS results, increase in per capita income in the province where Çorum is selling increases the sales volume of Çorum with that provinces. On the other hand, the increase in the distance between Çorum and the provinces it sells reduces the sales amount of Çorum.

Eventually Çorum has great potential to develop commercial relations with its neighbors. It has been determined that sales of Çorum to Yozgat, Amasya and Kırıkkale are below or slightly above the potential. It is thought that further deepening and development of existing commercial relations with these provinces will contribute more to the trade volume of Corum. Commercial sales volume of Çorum to these provinces should be increased with an investment plan for certain products that these provinces transfer resources in the industry and agriculture sector. In this context, considering the needs of the foreign market, the product range produced for industry and agriculture in Çorum should be expanded. The deepening commercial relations of Çorum with these provinces will contribute more to its total sales. On the other side, Çorum perform commercial sales with Kayseri, Sivas, Nevşehir, Karabük, Aksaray, Niğde, Bartın, Düzce and Zonguldak, which are relatively close to Çorum, below its potential. The deepening of relations with these provinces may differentiate Çorum's economy from other cities in a positive way. It is thought that the sales of Çorum to these provinces will increase by increasing the agricultural productivity by using modern agricultural techniques. This may increase the commercial income of Çorum from its annual sales and per capita income of Çorum.

Peer-review: Externally peer-reviewed.

Conflict of Interest: The author declare that there is no conflict of interest.

Funding: The author received no financial support for the research, authorship and/or publication of this article.

Ethical Approval: This article does not contain any studies with human participants or animals performed by the author.

Author Contributions: Muhammed Hasan Yücel (100\%)

\section{KAYNAKÇA}

Abraham, F., and Hove, J. V. (2005). The rise of China: prospects of regional trade policy. Review of World Economics, 141(3), 486-509. doi: 10.1007/s10290-005-0040-x

Ata, S. (2013). Türkiye ile komşuları arasındaki ticaret potansiyeli: çekim modeli çerçevesinde bir inceleme. Sarı, S., Gencer, A. H. and Sözen, İ. (Ed.) In international conference on Eurasian economies 2013 (pp. 500-509). Ankara: Beykent University. Retrieved from: https://www.avekon.org/proceedings/avekon04.pdf

Batra, A. (2004). India's trade potential: the gravity model approach. (Working paper no.151). New Delhi: Global Economic Review/Indian Council for Research on International Economic Relations. doi: 10.1080/12265080600888090

Bindak, R. (2015). İller arası göç tahmini için bir çekim (cazibe) modeli önerisi. Sosyal Bilimler Araştırma Dergisi, 4(2), 111-120. Retrieved from: https://dergipark.org.tr/tr/download/article-file/208886

Çorum İl Gıda Tarım ve Hayvancılık Müdürlüğü. (2017). 2017 Yılı brifing raporu. Çorum: Çorum İl Gıda Tarım ve Hayvancılı Müdürlüğü. Retrieved from: https: / / corum.tarimorman.gov.tr/Belgeler/2017\%20YILI\%20BR\%C4\%B0F\%C4\%B0NG\% 20RAPORU.pdf 
Gencer, A., H., and Öngel, V. (2011). Serbest ticaret bölgesi çerçevesinde Türkiye ile Suriye, Ürdün ve Lübnan arasındaki potansiyel dış ticaret hacminin uluslararası çekim modeli yoluyla tahmini. Trakya Üniversitesi Sosyal Bilimler Dergisi, 13(1), 71-94. Retrieved from: https://dergipark.org.tr/tr/download/article-file/321539

Golovko, A. (June 2009). Çekim modeli: aurasya ülkelerinin diş ticareti [Report]. Anadolu Uluslararası İktisat Kongresi, 17-19 June 2009, Eskişehir, Turkey. Retrieved from: https://www.academia.edu/375375/\%C3\%87ekim_Modeli_Avrasya_\%C3\%9Clkelerinin_ D\%C4\%B1\%C5\%9F_Ticareti

Karayolları Genel Müdürlüğü. (2020). Retrieved from: https://www.kgm.gov.tr/SiteCollection Documents/KGMdocuments/Root/Uzakliklar/ilmesafe.xls

Kucharčuková, O. B., Babecký, J., and Raiser, M. (2010). A gravity approach to modelling international trade in south-eastern Europe and the commonwealth of independent states: the role of geography, policy and institutions. Open Economies Review, 23(2), 277-301. doi: $10.1007 / \mathrm{s} 11079-010-9187-8$

Ram, Y. and Prasad, B. (n.d.). Assessing Fiji's global trade potential using the gravity model approach. Retrieved from: https://citeseerx.ist.psu.edu/viewdoc/download? doi=10.1.1.505.4723\&rep=rep $1 \&$ type $=$ pdf

Ratnayake, R. and Townsend, B. (1999). The geographical pattern of New Zealand's international trade: an application of the gravity model. New Zealand Economic Papers 33(2), 27-38. Retrieved from: https://doi.org/10.1080/00779959909544306

T.C. Bilim, Sanayi ve Teknoloji Bakanlığı. (2017). Girişimci Bilgi Sistemi. Retrieved from: https://gbs.sanayi.gov.tr

Tatlıcı, Ö., and Kızıltan, A. (2012). Çekim modeli: Türkiye'nin ihracatı üzerine bir uygulama. Atatürk Üniversitesi İ̈BF Dergisi, 25(0), 287-299. Retrieved from: https://dergipark.org.tr/tr/download/article-file/30446

TÜIKK. (2017). Adrese Dayalı Nüfus Kayıt Sistemi. Retrieved from: https:/ / data.tuik.gov.tr/Bulten/Index?p=Adrese-Dayali-Nufus-Kayit-Sistemi-Sonuclari2017-27587

Yaşar, E., and Korkmaz, İ. (2018). Çekim modelinin iller arası ticaret ilişkilerine uygulanması: Kütahya örneği. Dumlupınar Üniversitesi Sosyal Bilimler Dergisi, 56, 97-114. Retrieved from: https://dergipark.org.tr/tr/download/article-file/463872 
Annex-1. The Differences Between the Real and Predicted Trade of the Provinces with Çorum

\begin{tabular}{|c|c|c|c|c|}
\hline obs & Actual & Fitted & Residual & Res \\
\hline ADANA & $17.9494 \ldots$ & $17.0603 \ldots$ & $0.88911 \ldots$ & 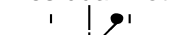 \\
\hline ADIYAMAN & $15.1753 \ldots$ & $15.1413 \ldots$ & $0.03399 \ldots$ & I \\
\hline AFYONKARAHISAR & $18.1722 \ldots$ & $16.4846 \ldots$ & $1.68763 \ldots$ & I \\
\hline AĞRI & $15.2740 \ldots$ & $14.2164 \ldots$ & $1.05760 \ldots$ & \\
\hline AKSARAY & $16.4564 \ldots$ & $17.3657 \ldots$ & $-0.9093 \ldots$ & \\
\hline AMASYA & $18.9462 .$. & $18.8385 \ldots$ & $0.10773 \ldots$ & I \\
\hline ANKARA & $20.8553 \ldots$ & $19.7681 \ldots$ & $1.08719 \ldots$ & I \\
\hline ANTALYA & $17.3685 \ldots$ & $16.6507 \ldots$ & $0.71776 \ldots$ & I \\
\hline ARDAHAN & $12.8597 \ldots$ & $13.3006 \ldots$ & $-0.4408 \ldots$ & \\
\hline ARTVIN & 15.2239. & $15.2696 \ldots$ & $-0.0456 \ldots$ & I \\
\hline AYDIN & $15.7973 \ldots$ & $15.6246 \ldots$ & $0.17270 \ldots$ & I \\
\hline BALIKESIR & $17.1817 \ldots$ & $16.1723 \ldots$ & $1.00936 \ldots$ & \\
\hline BARTIN & $15.3758 \ldots$ & $16.7010 \ldots$ & $-1.3252 \ldots$ & \\
\hline BATMAN & $16.2036 \ldots$ & $15.8687 \ldots$ & $0.33492 \ldots$ & \\
\hline BAYBURT & 14.8912.. & $14.2266 \ldots$ & $0.66458 \ldots$ & I \\
\hline BILECIK & $15.5055 \ldots$ & $16.3978 \ldots$ & $-0.8922 \ldots$ & \\
\hline BINGÖL & $14.8549 \ldots$ & $14.7201 \ldots$ & $0.13480 \ldots$ & 1 \\
\hline BiTLIS & $14.7984 \ldots$ & $14.9992 \ldots$ & $-0.2007 \ldots$ & 1 \\
\hline BOLU & $17.7232 \ldots$ & $17.8341 \ldots$ & $-0.1109 \ldots$ & 1 \\
\hline BURDUR & $15.1640 \ldots$ & $16.4999 \ldots$ & $-1.3358 \ldots$ & \\
\hline BURSA & $18.7655 \ldots$ & $17.7525 \ldots$ & $1.01300 \ldots$ & \\
\hline ÇANAKKALE & $15.5321 \ldots$ & $15.4018 \ldots$ & $0.13023 \ldots$ & $\mathrm{I}$ \\
\hline CANKIRI & $18.5095 \ldots$ & $18.2989 \ldots$ & $0.21058 \ldots$ & $\mathrm{I}$ \\
\hline DENIZLİ & $17.8584 \ldots$ & $17.3865 \ldots$ & $0.47187 \ldots$ & I \\
\hline DIYARBAKIR & $17.6679 \ldots$ & $15.9571 \ldots$ & $1.71080 \ldots$ & 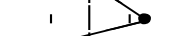 \\
\hline DÜZCE & $15.6076 \ldots$ & $17.2477 \ldots$ & $-1.6400 \ldots$ & 1 \\
\hline EDIRNE & $15.7414 \ldots$ & $15.8275 \ldots$ & $-0.0861 \ldots$ & 1 \\
\hline ELAZIĞ & $15.9303 \ldots$ & $16.2594 \ldots$ & $-0.3291 \ldots$ & I \\
\hline ERZINCAN & $15.5288 \ldots$ & $15.8084 \ldots$ & $-0.2795 \ldots$ & \\
\hline ERZURUM & $16.9210 \ldots$ & $15.7172 \ldots$ & $1.20376 \ldots$ & I \\
\hline ESKISSEHIR & $16.9173 \ldots$ & $17.2715 \ldots$ & $-0.3542 \ldots$ & \\
\hline GAZIANTEP & $19.6367 \ldots$ & $17.4940 \ldots$ & $2.14268 \ldots$ & I \\
\hline GIRESUN & $17.2847 \ldots$ & $16.4914 \ldots$ & $0.79324 \ldots$ & 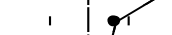 \\
\hline GÜMÜŞHANE & $15.1138 \ldots$ & $14.5253 \ldots$ & $0.58852 \ldots$ & \\
\hline HAKKARI & $12.2238 \ldots$ & $13.3367 \ldots$ & $-1.1129 \ldots$ & 1 \\
\hline HATAY & $16.2714 \ldots$ & $17.1609 \ldots$ & $-0.8895 \ldots$ & . \\
\hline IĞDIR & 14.5492.. & $14.0897 \ldots$ & $0.45949 \ldots$ & 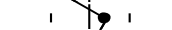 \\
\hline ISPARTA & $15.8617 \ldots$ & $15.8353 \ldots$ & $0.02639 \ldots$ & I \\
\hline ISTANBUL & $21.3055 \ldots$ & $18.9745 \ldots$ & $2.33094 \ldots$ & ' \\
\hline IZMiR & $18.1048 \ldots$ & $17.4391 \ldots$ & $0.66561 \ldots$ & \\
\hline KAHRAMANMARAŞ & $16.8185 \ldots$ & $16.9039 \ldots$ & $-0.0853 \ldots$ & \\
\hline KARABÜK & $17.7384 \ldots$ & $18.6443 \ldots$ & $-0.9059 \ldots$ & \\
\hline KARAMAN & $14.7582 .$. & $16.9373 \ldots$ & $-2.1790 \ldots$ & \\
\hline KARS & $15.9259 \ldots$ & $13.7438 \ldots$ & $2.18210 \ldots$ & \\
\hline KASTAMONU & $18.0838 \ldots$ & $17.7568 \ldots$ & $0.32706 \ldots$ & \\
\hline KAYSERI & $18.4100 \ldots$ & $18.4278 \ldots$ & -0.0177 & I \\
\hline KIRIKKALE & $18.3983 \ldots$ & $18.2756 \ldots$ & $0.12272 \ldots$ & 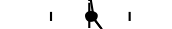 \\
\hline KIRKLARELI & $16.5255 \ldots$ & $15.8091 \ldots$ & $0.71639 \ldots$ & 1 \\
\hline KIRŞEHIR & $17.9808 \ldots$ & $17.7033 \ldots$ & $0.27746 \ldots$ & \\
\hline KíLis & $13.2065 \ldots$ & $16.0477 \ldots$ & -2.8 & 1 \\
\hline KOCAELİ & $17.4472 \ldots$ & $19.0193 \ldots$ & $-1.5721 \ldots$ & 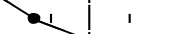 \\
\hline KONYA & $18.4870 \ldots$ & $17.9031 \ldots$ & $0.58397 \ldots$ & \\
\hline KÜTAHYA & $15.5502 \ldots$ & $16.1069 \ldots$ & $-0.5566 \ldots$ & \\
\hline MALATYA & $16.3345 \ldots$ & $15.8869 \ldots$ & $0.44765 \ldots$ & I \\
\hline MANISA & $17.2261 \ldots$ & $16.2717 \ldots$ & $0.95435 \ldots$ & I \\
\hline MARDIN & $18.4382 \ldots$ & $15.9627 \ldots$ & $2.47545 \ldots$ & I \\
\hline MERSIN & $17.7808 \ldots$ & $17.0319 \ldots$ & $0.74888 \ldots$ & \\
\hline MUĞLA & $15.4036 \ldots$ & $15.8984 \ldots$ & $-0.4947 \ldots$ & $\mathrm{I}$ \\
\hline MUŞ & $14.1736 \ldots$ & $16.4622 \ldots$ & $36 \ldots$ & 1 \\
\hline NEVŞEHIIR & $16.6014 \ldots$ & $17.5554 \ldots$ & $-0.9539 \ldots$ & 1 \\
\hline NIĞDE & $15.3249 \ldots$ & $16.6934 \ldots$ & $-1.3684 \ldots$ & I \\
\hline ORDU & $17.9101 \ldots$ & $17.0627 \ldots$ & $0.84748 \ldots$ & \\
\hline OSMANIYE & $14.8433 \ldots$ & $16.2981 \ldots$ & $-1.4548 \ldots$ & 1 \\
\hline RIZE & $17.1126 \ldots$ & $16.6959 \ldots$ & $0.41669 \ldots$ & \\
\hline SAKARYA & $16.8630 \ldots$ & $17.8390 \ldots$ & $-0.9760 \ldots$ & I \\
\hline SAMSUN & $20.0157 .$. & $18.6037 \ldots$ & $1.41206 \ldots$ & \\
\hline SIIRT & $14.3541 \ldots$ & $15.2247 \ldots$ & $-0.8706 \ldots$ & I \\
\hline SINOP & $16.7882 \ldots$ & $16.0841 \ldots$ & $0.70404 \ldots$ & 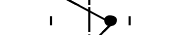 \\
\hline SIVAS & $17.0078 \ldots$ & $17.1459 \ldots$ & $-0.1380 \ldots$ & 1 \\
\hline ŞANLIURFA & $15.7429 \ldots$ & $15.8899 \ldots$ & $-0.1470 \ldots$ & 1 \\
\hline ŞIRNAK & $15.0028 \ldots$ & $14.8951 \ldots$ & $0.10775 \ldots$ & 1 \\
\hline TEKIRDAĞ & $16.2306 \ldots$ & $16.8486 \ldots$ & -0.6179 & \\
\hline TOKAT & $18.4845 \ldots$ & $17.3545 \ldots$ & $1.13005 \ldots$ & \\
\hline TRABZON & $18.1085 \ldots$ & $16.6817 \ldots$ & $1.42684 \ldots$ & \\
\hline TUNCELİ & $11.0500 \ldots$ & $14.4767 \ldots$ & $-3.4267 \ldots$ & 1 \\
\hline UŞAK & $15.3349 \ldots$ & $16.7073 \ldots$ & $-1.3724 \ldots$ & 1 \\
\hline VAN & $16.2313 \ldots$ & $14.8666 \ldots$ & $1.36471 \ldots$ & $>$ \\
\hline YALOVA & $15.6604 \ldots$ & $17.1392 \ldots$ & $-1.4788 \ldots$ & 1 \\
\hline YOZGAT & $18.7066 \ldots$ & $18.8576 \ldots$ & $-0.1509 \ldots$ & 1 \\
\hline ZONGULDAK & $15.9355 \ldots$ & $17.9759 \ldots$ & $-2.0403 \ldots$ & I \\
\hline
\end{tabular}


Muhammed Hasan YÜCEL

Annex-2. Potential Trade of Provinces by Distance to Çorum

\begin{tabular}{|c|c|c|c|c|c|}
\hline Provinces & Residuals & Distances (Km) & Provinces & Residuals & Distances (Km) \\
\hline Amasya & 0,11 & 92 & Tunceli & $-3,43$ & 589 \\
\hline Yozgat & $-0,15$ & 108 & Elazı̆̆ & $-0,33$ & 610 \\
\hline Çankırı & 0,21 & 156 & İstanbul & 2,33 & 614 \\
\hline Kirıkkale & 0,12 & 166 & Uşak & $-1,37$ & 616 \\
\hline Samsun & 1,41 & 172 & Gaziantep & 2,14 & 618 \\
\hline Tokat & 1,13 & 178 & Bursa & 1,01 & 626 \\
\hline Kastamonu & 0,32 & 197 & Isparta & 0,03 & 627 \\
\hline Kırşehir & 0,28 & 220 & Osmaniye & $-1,45$ & 647 \\
\hline Ankara & 1,09 & 241 & Erzurum & 1,20 & 648 \\
\hline Sinop & 0,70 & 266 & Burdur & $-1,34$ & 670 \\
\hline Kayseri & $-0,02$ & 281 & Kilis & $-2,84$ & 678 \\
\hline Sivas & $-0,14$ & 284 & Adiyaman & 0,03 & 699 \\
\hline Nevşehir & $-0,95$ & 296 & Hatay & $-0,89$ & 715 \\
\hline Karabük & $-0,91$ & 311 & Denizli & 0,47 & 723 \\
\hline Ordu & 0,85 & 323 & Antalya & 0,72 & 733 \\
\hline Aksaray & $-0,91$ & 330 & Bingö1 & 0,13 & 733 \\
\hline Bolu & $-0,11$ & 352 & Artvin & $-0,05$ & 739 \\
\hline Giresun & 0,79 & 367 & Tekirdağ & $-0,62$ & 745 \\
\hline Niğde & $-1,37$ & 374 & Şanlıurfa & $-0,15$ & 755 \\
\hline Bartin & $-1,32$ & 380 & Diyarbakır & 1,71 & 763 \\
\hline Düzce & $-1,64$ & 397 & Balıkesir & 1,01 & 777 \\
\hline Zonguldak & $-2,04$ & 411 & Manisa & 0,95 & 811 \\
\hline Konya & 0,58 & 419 & K1rklareli & 0,72 & 825 \\
\hline Erzincan & $-0,28$ & 458 & İzmir & 0,67 & 827 \\
\hline Sakarya & $-0,98$ & 466 & Ağrı & 1,06 & 828 \\
\hline Eskişehir & $-0,35$ & 482 & Muş & $-2,29$ & 840 \\
\hline Kocaeli & $-1,57$ & 503 & Edirne & $-0,09$ & 844 \\
\hline Trabzon & 1,43 & 503 & Aydin & 0,17 & 846 \\
\hline Afyonkarahisar & 1,69 & 505 & Ardahan & $-0,44$ & 847 \\
\hline Gümüşhane & 0,59 & 525 & Kars & 2,18 & 851 \\
\hline Karaman & $-2,18$ & 530 & Mardin & 2,48 & 859 \\
\hline Malatya & 0,45 & 530 & Batman & 0,33 & 863 \\
\hline Kahramanmaraş & $-0,09$ & 542 & Muğla & $-0,49$ & 868 \\
\hline Bayburt & 0,66 & 547 & Çanakkale & 0,13 & 897 \\
\hline Kütahya & $-0,56$ & 560 & Bitlis & $-0,20$ & 923 \\
\hline Bilecik & $-0,89$ & 565 & Iğdır & 0,46 & 939 \\
\hline Yalova & $-1,48$ & 568 & Siirt & $-0,87$ & 949 \\
\hline Mersin & 0,75 & 574 & Şırnak & 0,10 & 1045 \\
\hline Rize & 0,42 & 578 & Van & 1,36 & 1058 \\
\hline Adana & 0,89 & 581 & Hakkâri & $-1,11$ & 1230 \\
\hline
\end{tabular}


Investigation on Trade of Çorum with Surrounding Provinces by Gravity Model

Annex-3: Graph 1. Trade of Çorum Potential with Other Provinces

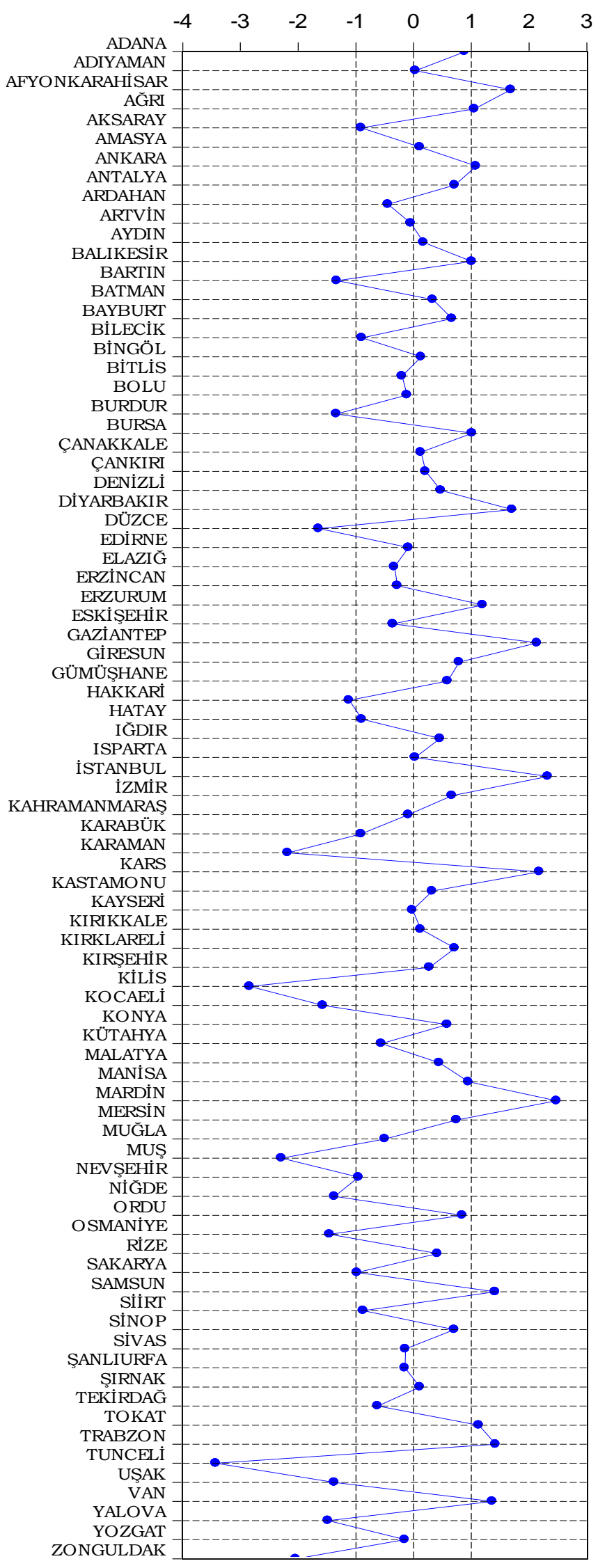




\section{GENIŞLETİLMIŞ ÖZET}

\section{Giriş}

Yerçekimi modeli ilk olarak 1962'de Jan Tinbergen tarafından ekonomide kullanılmıştır. Jan Tinbergen, bu modelle, ülkelerin GSYİH verileri göz önüne alındığında fiziksel ağırlığa sahip bir nesne olarak algılanabileceğini ve aralarındaki mesafeyi göz önünde bulundurarak birbirleriyle ticari ilişkilerin fiziksel olarak gerçekleştirilebileceğini ifade etmektedir.

Taşıma maliyetleri nedeniyle ülkeler arasındaki mesafe arttıkça, ticaret hacmi azalır. Ülkenin milli geliri arttıkça, alım gücü artacaktır. Alım gücü arttıkça da ticaret hacmi artacaktır. Başka bir ifade ile, ülkeler arasındaki ticaret hacmi ile mesafe arasında negatif yönlü bir ilişki bulunurken, milli gelir ile ticaret hacmi arasında pozitif yönlü bir ilişki vardır.

Bu ilişkiler Newton'un ünlü yerçekimi modeline uyarlanmıştır. Bu yasaya göre, kütleye sahip iki cisim arasında bir yerçekimi kuvveti vardır ve bu yerçekimi kuvveti, cisimlerin kütleleri ile doğru orantılı, cisimler arasındaki mesafe ile ters orantılıdır. Bu durumda ülkeler arasındaki mesafe gerçekleşen ticaret hacmi ile negatif yönde ilişkiliyken, ülkelerdeki insanların kişi başına gelirleri ile pozitif yönde ilişkili olmaktadır.

Bu çalışmada Çorum'un komşuları ve diğer iller ile olan ticari ilişkileri Çekim Modeli ile analiz edilmektedir. Yerçekimi Modeli, uluslararası ticaret, turizm ve göç çalışmalarında literatürde çokça kullanılmıştır. Ancak bu model iller arası ticari ilişkilerin yapısını incelemek için yalnızca bir çalışmada kullanılmıştır. Bu açıdan bu çalışmanın ikinci çalışma olacağı ve 2017 verileri kullanılarak daha güncel bir çalışma olması açısından literatüre katkı sağlayacağ1 söylenebilir. Ayrıca bu çalışma, Çorum için bu konuda yapılan ilk çalışmadır. Literatüre baktığımızda kapsamın farklı olduğu ancak modelin aynı olduğu birçok çalışma vardır.

\section{Veri, Yöntem ve Bulgular}

Bu çalışmanın verileri Bilim, Sanayi ve Teknoloji Bakanlığı, Girişimci Bilgi Sisteminden alınmıştır. Yalnızca 2017 verileri mevcut olduğundan, çalışma 2017 verileriyle sınırlıdır. İller arası uzaklık Karayolları Genel Müdürlüğü verilerine dayanmaktadır. Çorum ve diğer 80 ilin iller arası ticaret analizinin yapıldığı araştırmada, Yerçekimi Modeline dayalı analiz, Olağan En Küçük Kareler Yöntemi ile E-views programında tahmin edilmiştir.

Tahmin sonuçlarına göre, Çorum'un yaptığı satış miktarı, satış yaptığı ildeki kişi başına düşen gelir ile pozitif yönde, sattığı il arasındaki mesafe ile negatif yönde ilişkilidir. OLS sonuçlarına göre, Çorum'un satış yaptığ1 ilde kişi başına düşen gelirin \%1 artması, Çorum'un yaptığ satış miktarını \%1,22 arttırmaktadır. Öte yandan Çorum ile satış yaptığı il arasındaki mesafenin \%1 artması, Çorum'un o ile yaptığı satış miktarını \%1,56 düşürmektedir. Diğer OLS (Robust OLS (M), Robust OLS (S) ve Robust OLS (MM)) tahminleri de aşağı yukarı aynı sonuçları vermektedir.

İllerin ticaret potansiyelinin üstünde mi yoksa altında mı olduğunu tespit etmek mümkündür. Tahmin edilen değerler (E) ile gerçek ticaret değerleri (A) arasındaki farka bakılır. E> A ise, ticaret akımı potansiyelin altında kalır. $\mathrm{E}<\mathrm{A}$ ise, ticaret akımı potansiyelin üzerindedir. Çorum, (E-A) değeri negatif olan illerle potansiyelinin üzerinde ticaret yaparken, pozitif olan illerle potansiyelinin altında ticaret yapmaktadır. Bu durumda Çorum ile Karaman, Kilis, Tunceli arasında büyük bir ticaret potansiyeli olduğu söylenebilir. Öte yandan Çorum, Mardin, İstanbul ve Kars ile potansiyelinin üzerinde bir ticarete sahiptir. 
Çorum'un komşularına baktığımızda ise sadece Yozgat ile yaptığı ticaretin potansiyelinin altında kaldığı tespit edilmiştir. Samsun, Çorum ile potansiyelinin çok üzerinde ticaret yapan il olmuştur. Diğer komşu iller potansiyelin biraz üzerindedir. Çorum'un bu iller ile olan ticareti, gelişen ticari imkanlarla çok daha fazla artma eğilimine sahiptir. Ayrıca Çorum'a görece yakın olup komşu olmayan iller de ticaret potansiyelinin altında kalmaktadır. Bu duruma uyum sağlayan en önemli iki il Nevşehir ve Karabük'tür. Bu iki il, Çorum'a yaklaşık 300 km uzaklıkta olmasına rağmen ticaret potansiyelin çok altındadır.

Potansiyelin altında ticarete yol açan tek faktör mesafe olmasa da bu faktörün ticaret hacmini etkileyen önemli bir parametre olduğu inkâr edilemez. Bu açıdan değerlendirildiğinde iller arası ticari potansiyelin yapısını etkileyen pek çok faktör vardır ancak bunlar bu çalışmada ceterisparibus olarak alınmıştır.

\section{Sonuç}

Çorum'un potansiyel ticaret hacminin incelendiği bu araştırmada, sonuçların Yerçekimi Modeli ile uyumlu olduğu tespit edilmiştir. Bu çalışmada aynı alandaki diğer çalışmalarla benzer sonuçlar elde edilmiştir. Örneğin; Türkiye için Kütahya ili özelinde yapılan bir çalışmada (Yaşar ve Korkmaz, 2018) illerin GSYH ile Kütahya ili arasında yapılan ticari satışlar arasında pozitif yönlü bir ilişki olduğu tespit edilmiştir. Ayrıca Kütahya'nın iller arası ticari satışları ve iller arasındaki mesafe ile negatif yönlü bir ilişki ortaya konulmuştur. Benzer başka bir çalışmada (Kucharčuková et al., 2010) ise ticaret hacmi üzerinde pazarlara olan uzaklığın kurumların kalitesinden daha az önemli olduğu sonucu tespit edilmiştir. Yine başka bir çalışmada (Ata, 2013) Türkiye'nin komşuları ile olan ticaret hacmi Yerçekimi Modeli ile araştırılmış ve Türkiye'nin komşuluk avantajını tam olarak kullanamadığı ve komşuları ile potansiyel ticaret hacminin altında bir ticaret gerçekleştirdiği tespit edilmiştir. Çalışmamızda ise Yerçekimi Modeli uluslararası ticaret yerine iller arası ticarete uyarlanarak benzer bir şekilde uygulanmıştır. Uygulama sonucunda yapılan tespitler literatürdeki diğer çalışmalar ile paralellik göstermektedir.

Bu çalışmanın literatüre katkısı, 2017 verileri ile Çorum özelinde yapılan ilk çalışma olmasıdır ve Türkiye'deki iller arası ticarete uygulanan ikinci (ilk çalışma Yaşar ve Korkmaz, 2018) çalışmadır. OLS sonuçlarına göre, Çorum'un satış yaptığı ilde kişi başına düşen gelirin artması, Çorum'un o il ile yaptığı satış miktarını arttırmaktadır. Öte yandan Çorum ile satış yaptığı iller arasındaki mesafenin artması da Çorum'un o illere yaptığı satış miktarını düşürmektedir.

Sonuç olarak Çorum, komşularıyla ticari ilişkiler geliştirme potansiyeline sahiptir. Çorum'un Yozgat, Amasya ve Kırıkkale'ye satışlarının potansiyelin altında veya biraz üzerinde olduğu tespit edilmiştir. Bu iller ile mevcut ticari ilişkilerin daha da derinleşmesi ve geliştirilmesinin Çorum'un ticaret hacmine daha çok katkı sağlayacağı düşünülmektedir. Sanayi ve tarım sektöründe bu illerin kaynak aktardığı belirli ürünlere yönelik bir yatırım planlaması ile Çorum'un bu illere olan ticari satış hacmi arttırılmalıdır. Bu bağlamda dış pazar ihtiyaçları göz önünde bulundurularak Çorum'da sanayi ve tarıma dönük üretilen ürün yelpazesi genişletilmelidir. Çorum'un bu iller ile derinleşen ticari ilişkileri toplam satışlarına daha fazla katkı sağlayacaktır. Öte yandan Çorum, Çorum'a nispeten yakın olan Kayseri, Sivas, Nevşehir, Karabük, Aksaray, Niğde, Bartın, Düzce ve Zonguldak ile potansiyelinin altında ticari satışlar gerçekleştirmektedir. Bu iller ile olan ilişkilerin derinleşmesi ise, Çorum ekonomisini diğer illerden olumlu bir şekilde farklılaştırabilir. Modern tarım teknikleri kullanılarak tarımsal verimliliğin yükseltilmesi ile Çorum'un bu illere olan satışlarının artacağı düşünülmektedir. Bu durum, Çorum'un yıllık satışlarından elde ettiği ticari geliri ve Çorum'daki kişi başına düşen geliri artırabilir. 